TAPROBANICA, ISSN 1800-427X. April, 2013. Vol. 05, No. 01: pp. 87-88.

(C) Taprobanica Private Limited, 146, Kendalanda, Homagama, Sri Lanka.

www.taprobanica.org

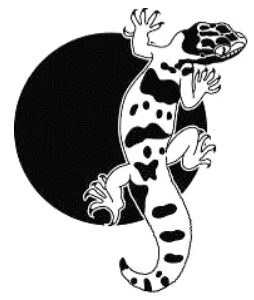

\section{Behaviour of Yunnan Giant Flying Squirrel (Petaurista yunnanensis) at a mineral lick in Yunnan, China}

In February 2012 one of us (Han) led an ecotour to Nankang Nature Reserve, west of the Nujiang (Salween) River, Baoshan Prefecture, Yunnan, and saw giant flying squirrels in the evening near the Nature Reserve headquarters. After hearing this, the Nature Reserve rangers began to take evening walks along the highway watching for flying squirrels, eventually discovering a mineral lick. In retrospect, the first observation in 2012 was evidently when the giant flying squirrels were approaching the lick site. On 24 February 2013 we observed the giant flying squirrels for about two hours, from 22:00 $\mathrm{hr}$ to midnight, as they approached the lick and returned from it.

Nankang Nature Reserve is in primary montane humid evergreen broad-leaved (oakrhododendron) forest. The elevation at the nature reserve headquarters about $300 \mathrm{~m}$ away and a little uphill was $2198 \mathrm{~m}$ (Garmin GPS). The lick is a steep cliff face that was cut for a two lane highway (county road S317) that was built between 1996 and 2000. Since the lick is on the south side the highway, and the giant flying squirrels approached from the north side, they had to cross the highway to obtain the minerals, and cross it again after licking. When approaching the lick, they had several specific routes through the forest that converged on a small tree. About 2 meters from the small tree was a larger tree, from which they launched their final glide to the lick. When approaching the small tree, they glided from one of several tall trees in the surrounding forest and landed near its base. They ran up the trunk to about 10 meters high (Figure 1), and then jumped to the large tree. From the top of the large tree, they glided to the lick, landing on the cliff face (Figure 2). The distance from this tree to the lick is an estimated 30-35 meters. Only one giant flying squirrel at a time attended the lick. During the 2 hours of observation, we saw about half a dozen individuals. Nature Reserve rangers report that, in any given night, up to 20 individuals may attend the lick.

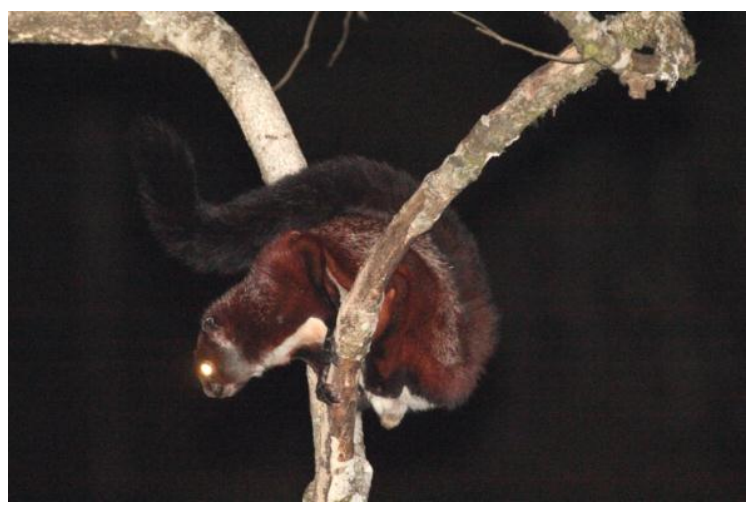

Figure 1: A Yunnan Giant Flying-squirrel prepares to jump to a larger tree, from which it will glide to the lick

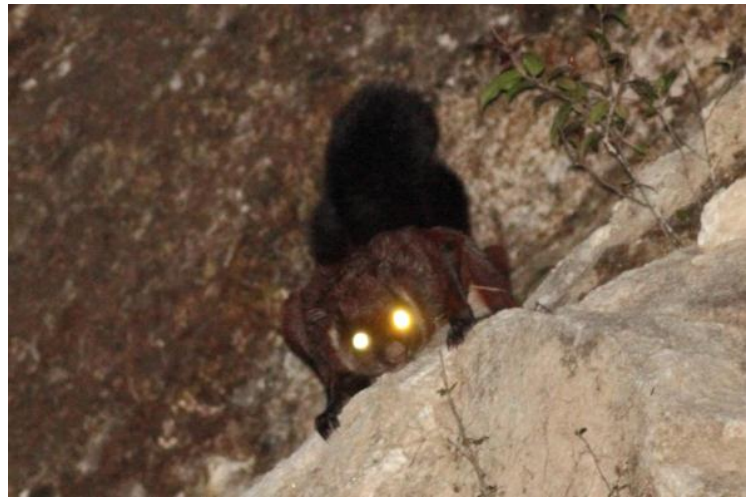

Figure 2: A Yunnan Giant Flying-squirrel at the mineral lick, looking down at observers

Petaurista species can glide over $100 \mathrm{~m}$ from high trees (Ando \& Shiraishi 1993; Francis 2008), but $P$. philippensis prefers short glides and averaged about $16 \mathrm{~m}$ per glide, with a maximum of $35 \mathrm{~m}$, in one study (Koli et al., 2011). Although Koli et al. (2013) concluded that construction of national highways was a potent factor in the decline of flying squirrels' populations, including Petaurista philippensis, the heavy truck traffic on county road S317, and the highway itself, appear not to impede 
crossing. The presence of high trees on both sides of the highway, and the high cliff on one side, no doubt enabled the giant flying squirrels to continue crossing the highway to use the lick. Retention of tall trees near highways is probably an important biological diversity connectivity corridor feature, and should be considered for conservation of obligate arboreal mammals such as flying squirrels. In this instance, truck disturbance is expected to be significantly reduced (perhaps $80 \%$ of the current traffic) after another highway (G56) is completed in a year or two, thus mitigating the impact.

P. yunnanensis was formerly considered a subspecies of $P$. philippensis, but genetic and morphological analysis shows it to be a distinct species (Francis, 2008, Oshida et al., 2004, Oshida et al., 2010, Song et al., 2012, Yu et al., 2006). It is sympatric in western Yunnan with at least four other Petaurista species: $P$. alborufus, $P$. caniceps, $P$. elegans, and $P$. petaurista; $P$. philippensis is broadly sympatric but occurs at lower elevations (up to $2000 \mathrm{~m}$ ), while $P$. xanthotis occurs in northwestern Yunnan, but in spruce forests at higher elevations (Francis, 2008, Smith \& Xie 2008).

\section{Literature Cited}

Ando, M., and S. Shiraishi. 1993. Gliding flight in the Japanese Giant Flying Squirrel Petaurista leucogenys. Journal of the Mammal Society of Japan, 18:19-32.

Francis, C. M., 2008. A guide to the mammals of southeast Asia. Princeton and Oxford, Princeton University Press: 392.

Koli, V. K., C. Bhatnagar and D. Mali, 2011. Gliding behaviour of Indian Giant Flying Squirrel Petaurista philippensis. Current Science, 100 (10): 1563-1568.

Koli, V. K., C. Bhatnagar and S. K. Sharma, 2013. Distribution and status of Indian Giant Flying Squirrel (Petaurista philippensis Elliot) in Rajasthan, India. National Academy Science Letters, 36 (1): 27-33.

Oshida, T., C. M. Shafique, S. Barkati, Y. Fujita, L.-K. Lin and R. Masuda, 2004. A preliminary study on molecular phylogeny of giant flying squirrels, genus Petaurista (Rodentia, Sciuridae) based on mitochondrial cytochrome $b$ gene sequences. Russian Journal of Theriology, 3: 1524.
Oshida, T., C. N. Dang, S. T. Nguyen, N. X. Nguyen, H. Endo, J. Kimura, M. Sasaki, A. Hayashida, A. Takano and Y. Hayashi, 2010. Phylogenetics of Petaurista in light of specimens collected from northern Vietnam. Mammal Study, 35: 85-91.

Smith, A. T. and Y. Xie (eds.), 2008. A guide to the mammals of China. Princeton, N.J. Princeton University Press: 544.

Song, L., Y. Fa-Hong and L. Xue-Fei, 2012. Cranial morphometric study of four giant flying squirrels (Petaurista)(Rodentia: Sciuridae) from China. Zoological Research, 33: 119-126.

Yu, F., F. Yu, J. Pang, C. W. Kilpatrick, P. M. McGuire, Y. Wang, S. Lu and C. A. Woods, 2006. Phylogeny and biogeography of the Petaurista philippensis complex (Rodentia: Sciuridae), inter-and intraspecific relationships inferred from molecular and morphometric analysis. Molecular Phylogenetics \& Evolution, 38: 755-766.

Submitted: 25 April 2013, Accepted: 31 May 2013 Sectional Editor: Colin Groves

Han Lian-Xian ${ }^{1} \&$ Lee Harding ${ }^{2}$

${ }^{1}$ Faculty of Life Science, Southwest Forestry University, 300, Bailongsi, Kunming, Yunnan, China

E-mail: lianxian.han@gmail.com

${ }^{2}$ SciWrite Environmental Sciences Ltd., 2339 Sumpter Drive, Coquitlam, British Columbia, Canada 